\section{First test of incineration}

\section{Boston}

IF all goes as planned this week, the US Army will destroy by incineration a first batch of chemical weapons at its new facility on remote Johnston Island in the Pacific Ocean. The trial incineration, which the Army calls "operational verification testing", is the first step in fulfilling the agreement between US President George Bush and Soviet President Mikhail Gorbachev earlier this year to destroy the bulk of the superpowers' vast chemical arsenals (see Nature 345, 192; 1990).

Although the chemical weapons agreement was widely welcomed, both sides acknowledge that destroying the weapons presents environmental dangers that could engender considerable political opposition. On the US side, the Johnston Island facility represents the US Army's attempt to show that the ageing chemical weapons can be disposed of safely. The incinerator was completed last year, before the recent agreements, to destroy a large stockpile of chemical weapons that had been stationed in the Pacific during the Second World War. These weapons, amounting to several thousand tons, have been stored since 1971 on Johnston Island, which is some 700 miles from its nearest Hawaiian neighbour.

Army chemists say that because the chemical components of the nerve, mustard and blister agents to be burned are known so preciseiy, and because of the facility's state-of-the-art design, it should generate fewer toxic emissions than conventional trash incinerators. But this optimistic view is not universal. Dozens of environmental groups have objected to the facility during the lengthy political process required for it to open, decrying the potential air pollution and toxic solid wastes generated by incineration and favouring alternative disposal methods.

Even as testing begins, Sebia Hawkins of Greenpeace says that there is "still hope that the facility can be stopped". But environmentalists concede that the Army has largely sidestepped opposition because the island is so remote and lacks a native population. Future incinerators to handle the vast bulk of the nation's stockpiles remain to be built, and are likely to generate far more political opposition.

Almost everyone involved in the project admits that a deadly accident could occur. As carefully designed as the handling procedures are, the sheer scale of the operation is worrying.

The Johnston Island facility will handle thousands of tons of lethal chemicals some of which can kill in microgram quantities - and burning all the chemical agents now stored on the island is expected to keep the incinerator running steadily for over a year.
Adding to the controversy is the fact that later this year another 430 tons of chemical weapons are scheduled to arrive at the island. The new intake comes from West Germany in the wake of an agreement in 1987 between then US President Ronald Reagan and German Chancellor Helmut Kohl that the United States would remove its chemical stockpile from German soil. The agreement stipulates that the weapons must be removed by the end of this year, but does not specify where they should go. Johnston Island is virtually the only place in the world that can handle them, so the plan is that the weapons will be moved by truck, rail and ship, under tight security, from Clausen, Germany, to Johnston Island.

All told, the Johnston Island facility is marked for the incineration of less than 7 per cent of the US stockpile. The current plan calls for the other 93 per cent to be incinerated in the continental United States, at military facilities in Alabama, Arkansas, Colorado, Indiana, Kentucky, Maryland, Oregon, and Utah. Public opposition is already mounting.

Meanwhile, the Soviet chemical weapons stockpile is said to be even larger than that of the United States, and the

Soviet destruction programme is in its infancy. The Soviet president has asked for US help with the Soviet effort to destroy chemical weapons, and collaboration is written into the formal agreement between the two countries. Elisa Harris, an expert on chemical and biological weapons at the Brookings Institution in Washington, says that the Soviet population has even less confidence in its government's ability to do the job than Americans have in the US chemical weapon destruction programme.

She calls the domestic Soviet problem part of a "post-Chernobyl syndrome". The political controversy generated in both countries is likely to make Johnston Island an important model for both sides. US experts have met already with Soviets in Geneva and Moscow to discuss technical issues of chemical weapon destruction, and a Soviet delegation is expected soon to visit a small-scale prototype US facility constructed several years ago at an Army base in Tooele, Utah. As Harris puts it, "the Soviets are clearly capable of destroying their own chemical weapons", but with the domestic political difficulties involved in carrying out such programmes in either country "it will be interesting to see just how much cooperation each side has in mind".

Seth Shulman

\title{
Tigret spells hope for endangered species
}

\section{Washington}

THE world's first test-tube tiger was put on display at the National Zoo in Washington DC last week. Although the cub was born two months ago, zoo officials have up until now not had the confidence to show it to the ᄃ zoo hopes will help to preserve endangered species. Mary Alice is a Siberian tiger, a rare subspecies of tiger of which only 200 remain in the wild. Seven hundred are kept in zoos around the world, which means that captive breeding provides the best chance of saving it from extinction.

The IVF technique is likely to be of particular help because it allows sperm from a valuable male in one country to be used to fertilize eggs from a partner in another country, without all the difficulties of transferring the animals themselves.

Since 1984, the National Zoo, in co-operation with Henry Doorly Zoo in Omaha and the Minnesota Zoo, has being working to adapt IVF techniques originally developed for humans. After IVF was used successfully with domestic cats, the technique was tried on the Siberian tiger. Three test-tube cubs were born in Henry Doorly Zoo on 27 April. A mobile IVF laboratory

Test-tube baby - the world's first IVF tiger. public. Two other cubs born at the same time died in their first weeks.

The cub, named Mary Alice, represents a \$2 million dollar investment in in vitro fertilization (IVF) technology which the developed by the National Zoo and taken to Omaha for the placement of the three fertilized eggs in the surrogate mother tiger will provide artificial breeding technology to other zoos in the future.

Shigeko Segawa 